\title{
2 Influence operations and other conflict trends
}

\author{
Marie Baezner and Sean Cordey
}

In the past decades, various scholars and politicians have warned about the advent of cyber war and the probable surge of cyber operations ${ }^{1}$ of possible catastrophic scale that could lead to the infamous "Cyber Pearl Harbor" (Shanker and Bumiller 2012). As Thomas Rid has pointed out in his book Cyber War Will Not Take Place, such operations have not become ubiquitous nor have they escalated into (cyber) war (Rid 2013). While cases in which cyber operations have been conducted to support other military operations in times of war have been observed (e.g. in Georgia or Ukraine), the cybersecurity literature has generally concluded that the majority of such operations takes place below the threshold of armed conflicts, an area that some international security scholars have called the "Gray Zone".

Accordingly, this chapter focuses on the socio-technological logics behind the emergence of gray zone conflicts and more specifically on the use of cyber operations, notably cyber-enabled influence operations, within them. To do so, the first section reviews the theoretical framework and driving factors of gray zone conflicts. The second section reviews some assumptions about cyber operations that make them attractive for gray zone conflicts before discussing, through a comparative analysis of various cases, their use.

As a caveat, this study was conducted on the basis of academic and open source literature. While these sources provided extensive information on cyber operations in gray zone conflicts, they primarily gave a Western point of view on the topic. The lack of literature on Western cyber operations in such conflicts gives the impression that actors targeting Western countries are more numerous and more active, which may not be the case.

\section{Gray zones conflict: A theoretical framework}

Geopolitical competition over the last decade has been increasingly played within the space beyond conventional diplomacy and short of conventional war, a space that is commonly referred to in the literature as the "Gray Zone". This concept was developed by scholars linked to the RAND Corporation and the US military (particularly special operations). It rose to preeminence at the same time as 
the concept of hybrid warfare (to which it is sometimes equated) following the Crimean and Ukrainian crises.

Gray zone (conflict) ${ }^{2}$ is a concept whose utility and definition are still debated. The main conceptual debate revolves around whether it is a new form of competition (Hicks et al. 2019; Hoffman 2007) or just an operational environment (Chambers 2016). The former interpretation is particularly aligned with US military phasing and planning (Pettyjohn and Wasser 2019). Critics, however, have argued that such a denomination has only contributed to conceptual muddling as it is not clear whether there are real boundaries between the phases and to what extent they can be applied in practice (Pettyjohn and Wasser 2019). As a result, part of the scholarship has moved away from it and is instead highlighting the latter understanding, to which the authors subscribe.

According to this strand of literature, gray zone conflicts have the following characteristics (Cantwell 2017; Chambers 2016; Corn 2018; Hicks et al. 2019; Pettyjohn and Wasser 2019; Votel et al. 2016): First, the gray zone is a distinct operating environment between peacetime diplomatic and geopolitical interactions and conventional war where intense political, economic, information, and military competition takes place. Gray zone conflicts thus mostly occur under the threshold of war. The array of techniques and tools used can also be employed once a conflict has escalated. Second, interactions within the gray zone are characterized by operational and strategic ambiguity, thereby allowing some degree of plausible deniability for its actors (Barno and Bensahel 2015; Mazarr 2015b). Third, gray zone conflicts are characterized by the opacity of the parties involved and the relative uncertainty about the relevant policy and legal frameworks that apply to them (Kapusta 2015). Fourth, leveraging the gray zone is (supposedly) mostly the province of revisionist powers, ${ }^{3}$ which try to achieve objectives normally associated with victory in war (Chambers 2016; Corn 2018). Finally, within the gray zone, boundaries between the private and public domain are blurred with states using and targeting various affiliated actors - state-owned or private entities (Hicks et al. 2019).

The means and tactics used in gray zones are legion, multidimensional, and span across the full spectrum of state power and capabilities. They are only limited by the bounded threshold (before war) and often not by traditional legal and functional categories (Hicks et al. 2019). As such, operations in gray zone conflicts can be undertaken in all five domains - i.e. air, land, space, sea, and cyber or information - and by any governmental actors (Chambers 2016). These operations are particularly suited for asymmetrical conflicts due to their cost effectiveness, small footprint, low visibility, and covert nature (Votel et al. 2016). Accordingly, Hicks et al. (2019) propose the following categorization of gray zone (non-kinetic) means and tactics: Information operations and disinformation; political coercion; economic coercion; cyber operations; space operations; and proxy support.

While the concept of gray zone conflicts is often presented as relatively new, the types of actions that it describes only reflects what states have been doing for centuries to advance their interests in a competitive international system (Brands 
2016; Dostri 2020; Mazarr 2015a, 2015b). Despite this, gray zones are effectively being increasingly leveraged through some new tools (e.g. cyber operations (CO) and cyber influence operations (CIO)) as states look for alternative ways to achieve their goals due to the rising cost of direct aggression (Dostri 2020; Echevarria 2016; Mazarr 2015b). Gray zone conflicts, meanwhile, are growing in saliency, intensity, and scale. This trend is driven by two factors: (1) the dynamics in the international (geo)strategic environments; and (2) the development and diffusion of new socio-technological means and methods (Corn 2018; Echevarria 2016; Mazarr 2015a).

Regarding the former, (1), the rise of gray zone conflicts is symptomatic of larger trends in the international environment such as accelerating geopolitical fragmentation, rising tensions and uncertainty as well as discontinuities in domestic politics around the world. At the domestic level, recent years have seen several nations such as Turkey, Poland, and the United States ravel in internal divisions and grievances, whether ethnical, economic, or political. These coupled with burgeoning illiberal and authoritarian regimes have set the stage and opened avenues for exploitation of the gray zone (e.g. electoral manipulation or influence campaigns).

At the international level, the exploitation of gray zones has become particularly attractive for non-state and state actors due, in part, to the current conventional nuclear superiority of the United States and the extensive economic interdependence, both of which have created a general aversion to major conventional wars (Mazarr 2015a). This is reinforced by the fact that some normative pillars of the international system are increasingly contested or that they simply do not exist (e.g. cyberspace) (Kapusta 2015). This fosters a legal gray zone that encourages bad behavior due to reduced risks of sanctions or escalation. Furthermore, international collaboration to counter this type of exploitation is made difficult by the loss of cohesion and difference in threat perception between like-minded states. These differences, alongside those between the private and public sectors, which are rooted and entangled in economic and political structures, not only complicate the identification of the problem but also the response to it (Dalton et al. 2019).

Regarding the latter, (2), the numerous socio-technical changes of the past decades, such as the widespread use of social media or the democratization of hacking tools, have been another driving cause for this trend. According to Leed (2015), technological advances (i.e. in Information and Communications Technology (ICT)) have allowed an unprecedented level of globalization, which, in turn, has blurred the distinctions between traditional elements of national power (e.g. between the military and commercial technologies) and between state and sub/ non-state actors. Moreover, the extensive diffusion of technology - particularly related to space, cyber, and information - coupled with the relative affordability of these allowed a diverse range of actors (from adversaries to partners) to gain new and more effective means for sub-threshold coercion (Hicks et al. 2019). The increasing use of and dependence on technology by all strata of modern society have also opened the door to a plethora of leverageable socio-technical vulnerabilities, such as the fact that most ICTs are not built with a security-first mindset. 
Meanwhile, efforts to mitigate these vulnerabilities are "often erratic, dependent on immature and ineffective market forces and regulatory schemes, and consistently outpaced by relatively low-cost exploitation technologies and techniques" (Corn 2018).

\section{Cyber operations in the gray zone}

Despite the numerous warnings and scholarship on the issue, the large-scale and systematic use of cyber operations as a means of warfare has remained in the realm of hypothesis unobserved in practice. As a result the literature now advances that cyber operations are instead largely seen as instruments of power, particularly in the gray zone literature (Boeke and Broeders 2018; Buchanan 2020; Fischerkeller and Harknett 2017; Gannon et al. 2021; Nye 2017; Sanger 2018). There are at least two strands within the literature on the strategic role of $\mathrm{CO}$, both echoing the larger debate (Fischerkeller and Harknett 2019; Rovner 2019). The first strand - in line with the view that gray zone conflicts represent a shift away from conventional war - views cyber operations as novel strategic instruments, which are supposedly greatly efficient and effective compared to other instruments, such as economic coercion. The second strand, meanwhile, contests this claim and instead argues that cyber operations are only contemporary instruments of a variety of conventional competition activities, such as espionage, intelligence, or covert operations. In both strands of the literature, however, cyber operations and cyber influence operations play a preeminent role as instruments of power.

To better understand the implications, another strand of the scholarship has focused on the practical use and effects of cyber operations and cyber influence operations in various gray zone conflicts, such as the Americano-Russian influence and espionage campaigns, the Syrian civil war, or the Ukrainian conflict (Al-Rawi 2014; Baezner and Robin 2017a, 2017c, 2018; Barrett 2019; Crowdstrike 2016; DiResta et al. 2018; Galperin et al. 2013; Giles 2016; Grohe 2015; Howard et al. 2018; Nocetti 2015; Ornos et al. 2017). Building upon these, the rest of this section is devoted to assessing, in light of a set of case studies summarized in Table $2.1,{ }^{4}$ three widely shared assumptions that make cyber operations and cyber influence operations attractive in the gray zones.

\section{Accessible and available}

The first widely shared assumption is that, apart from highly sophisticated cyber operations (e.g. Stuxnet or Blackenergy II) that require and exploit expensive and rare zero-day vulnerabilities, the majority of cyber technologies and tools for disruptive and cyber influence operations have effectively become widely available and at a relatively low cost. As a result, and as Smeets posits, "the availability of offensive cyber capabilities expands the options available to state leaders across a wide range of situations" (2018: 92), particularly in the gray zone.

Indeed, regarding availability, the underground forums and black markets for malware are today filled with "ready to be used" attack tools and "ready to 
Table 2.1 Case study summary

\begin{tabular}{|c|c|c|}
\hline Case study & Actors & Types of cyber operations \\
\hline US-Russia & State-sponsored actors & $\begin{array}{l}\text { Cyberespionage and cyber-enabled } \\
\text { influence }\end{array}$ \\
\hline Ukraine & $\begin{array}{l}\text { Non-state actors, hacktivists, } \\
\text { and state-sponsored actors }\end{array}$ & $\begin{array}{l}\text { Disruption, cyberespionage, } \\
\text { sabotage, and cyber-enabled } \\
\text { influence }\end{array}$ \\
\hline Syria & $\begin{array}{l}\text { Non-state actors, hacktivists, } \\
\text { and state-sponsored actors }\end{array}$ & $\begin{array}{l}\text { Disruption, cyberespionage, and } \\
\text { cyber-enabled influence }\end{array}$ \\
\hline US-China & State-sponsored actors & Cyberespionage \\
\hline North Korea & State-sponsored actors & $\begin{array}{l}\text { Cyberespionage, cybercrime, and } \\
\text { sabotage }\end{array}$ \\
\hline India-Pakistan & $\begin{array}{l}\text { Non-state actors, hacktivists, } \\
\text { and state-sponsored actors }\end{array}$ & $\begin{array}{l}\text { Disruption, cyberespionage, and } \\
\text { cyber-enabled influence }\end{array}$ \\
\hline Southeast Asia & $\begin{array}{l}\text { Non-state actors, hacktivists, } \\
\text { and state-sponsored actors }\end{array}$ & Disruption and cyberespionage \\
\hline Iran & State-sponsored actors & $\begin{array}{l}\text { Cyberespionage, sabotage, and } \\
\text { online influence }\end{array}$ \\
\hline
\end{tabular}

be launched" cyber operations, such as Distributed Denial of Service (DDoS). One can also easily contract "hack-for-hire" hacker groups (e.g. Dark Basin) to perform a variety of hacks (Scott-Railton et al. 2020). Meanwhile, the technical knowledge needed to engage in basic cyber operations and cyber influence operations is also relatively low. For the latter, for instance, only a rudimentary understanding of widely available editing software (e.g. meme editors, tweet generators or deepfakes) and social media is necessary (Chesney and Citron 2018).

Regarding costs, David Sanger (2018) advances that cyber weapons necessary for cyber operations are now "so cheap to develop and so easy to hide that they have proven irresistible". Indeed, the cost of entry to engage in cyber operations of low to medium sophistication is also relatively low, notably when compared to other traditional military means. This is particularly the case for cyber influence operations, which only require an internet connection, an internet-enabled device, and access to free account-based applications to engage in disinformation or propaganda. The cost of maintenance of these cyber weapons, however, can vary (Smeets 2018). But at the same time, the cost and time of execution can be further reduced through optimization and the use of more sophisticated tools and techniques, such as automated bots.

Looking at our cases, a first observation is that cyber operations tended to be more disruptive (affecting the logical and/or persona layers of cyberspace) than destructive (affecting the physical layer of cyberspace). This tendency is partly due to the fact that destructive cyber operations are less accessible than disruptive ones. Indeed, destructive cyber operations are more sophisticated and require more resources to be developed and planned, as shown by Stuxnet. Furthermore, destructive cyber operations have more escalatory potential than disruptive ones, 
making the latter more appropriate for gray zone conflicts. In our case studies, states and state-sponsored actors have shown restraint in their exploitation of cyber operations despite them being increasingly used due to rising international tensions (Gomez 2018; Valeriano and Jensen 2019). Apart from Stuxnet and other cyber operations targeting high-value targets such as Ukraine's electric grid in 2015 and 2016, the effects of cyber operations have remained limited (Cherepanov 2017; Dragos Inc. 2017).

Accordingly, this restraint could derive from the following two points. First, it may simply reflect that states are willing and eager to keep tensions only within the gray zone, even in open conflicts such as in Ukraine. This restraint also indicates that states seem to recognize and respect some "red lines" to avoid escalation (Gomez 2018). Consequently, this restraint shows that states are aware that their behavior in cyberspace can shape discourses on international norms and may want to remain at a level below the threshold of war to avoid precedents. Second, the restraint may simply be linked to inherent difficulties of conducting cyber operations. They require significant costs and time investments, they are difficult to control, their effects are uncertain and difficult to measure, and tools may only be used once in a specific timeframe ${ }^{5}$ (Gomez 2018). All these elements make states prefer to reserve their most destructive cyber operations for the time they will most need them (e.g. for war). From a cost-benefit point of view, it is also possible that physical attacks may be simpler, cheaper, and more impressive than cyberattacks.

A second observation derived from our case study is that some states also conduct cybercrime activities in the gray zone, thus reinforcing the fact that cyberspace is well suited for different activities below the threshold of war. The state that best illustrates this particularity is the Democratic People's Republic of North Korea (DPRK). Indeed, the DPRK has been conducting cybercrime activities to finance its regime, its nuclear program, and to circumvent international sanctions (Carlisle and Izenman 2019; Kim 2018; Sanger 2018). A UN report published in 2019 declared that the DPRK's government earned approximately US\$2 billion through cybercrime activities (e.g. targeting banks and cryptocurrency exchanges in foreign countries) (Finkle 2017; Guerrero-Saade and Moriuchi 2018; Nichols 2019; Solon 2017).

These DPRK's operations clearly stand out from the other states' that very rarely include cybercrime. In China and Russia, the divide between cybercrime and state-sponsored operations is blurry or at least permeable - a defining characteristic of gray zone conflicts. Indeed, these states often hire contractors that may also conduct cybercrime when they are not under contract with governments. For instance, APT41, working for the Chinese Ministry of State Security (MSS), conducts cyberespionage operations by day and cybercrime activities by night. However, FireEye noticed that the latter were conducted outside regular Chinese office hours and therefore were likely conducted without the state's knowledge or at least with the state's tolerance but likely not under the state's contract (FireEye Inc. 2019). In this example, the state is not the beneficiary of the financial gains perpetrated by these cybercrime operations and might actually suffer from the unwanted attention they generated. 


\section{Operationally attractive and effective}

A second assumption that renders cyber operations operationally attractive, notably in the gray zone, is that cyber technologies leveraged by cyber operations and cyber influence operations enable rapid and scalable effects, two characteristics which enhance their effectiveness as they lead to the surprise, overload, and paralysis targets (Harknett and Smeets 2020; Warner 2019; Wirtz 2017). In practice, the nearly instantaneous nature of the internet and the interconnectivity of all ICTs have nullified the execution time between the launch and impact of an attack. Regarding cyber influence operations, cyber technologies have drastically reduced the time needed to disseminate information while offering a wide flexibility and range of platforms and formats. Concurrently, cyberspace has - to some degree - removed traditional physical and national barriers, thus providing even more operational scalability, flexibility, and security for its operators. This is also true for cyber influence operations where the new digital means of information dissemination, free from traditional information gatekeepers, have greatly expanded the reach and scale of influence activities.

Accordingly, one observation from our case study is that cyber operations are indeed increasingly used to gain a strategic advantage but particularly through cyberespionage campaigns, as illustrated by the PLA-sponsored Operation Aurora or the hacks of the American military Sea Dragon project (Nakashima and Sonne 2018). As such, this tends to imply that, in accordance with one strand of the literature, cyber operations are more used as a vector for traditional facets of competition in the gray zone rather than a purely novel instrument. In addition to the operational advantages of cyber operations, this can be in part explained by the fact that cyberespionage is not regulated by international law, which allows states to use such operations with relative impunity. However, some states, like the United States, make a distinction between economic espionage and national security espionage. While both types can be used in gray zone conflicts, these states consider the former to be illegal, while the latter is tolerated (Harris 2016; The Economist 2013).

A second observation is that cyber influence operations have gained in importance in the past years, as illustrated by the Russian influence campaign during the 2016 US Presidential election. Among others, these operations have used social media and tools to try to influence opinions on specific political topics. Such cyber operations are particularly well suited for gray zone conflicts as they are relatively cost effective, flexible, and easy to organize and limit escalation. As a result of the 2016 US election, some states have even started to mimic Russian influence techniques against, in parts, Western states. This was particularly the case of Iran during the 2018 US midterm elections but with less sophisticated cyber operations than Russia (Barrett 2019; Dave and Bing 2019; Timberg and Romm 2019).

A last observation is that disruptive cyber operations (e.g. DDoS and website defacement) are often opportunistically used following certain political events, such as a protest or a territorial dispute (e.g. Pakistani patriotic hackers targeting Indian websites with DDoS and/or website defacement attacks after a physical 
clash on the Line of Control in the disputed region of Kashmir) (Balduzzi et al. 2018; Kozy 2015; Mogato 2017). These operations are not specifically sophisticated as they often use old vulnerabilities in websites and are easy and fast to organize (Dewar 2017). However, they particularly attract attention and are tangible. When a website is unavailable because of a DDoS attack, the costs are estimated to be US $\$ 22,000$ per minute of unavailability (Kenig 2013; NSFocus Inc. 2016). While the economic costs of such cyber operations can be significant, the political consequences of such operations remain rather limited. This limitation reduces risks of escalation and is particularly fitting in the context of a gray zone conflict. Patriotic hackers ${ }^{6}$ are the main actors involved in these disruptive cyber operations (Baezner 2018a, 2018c, 2018b, 2018d; Baezner and Robin 2017a, 2017b, 2017d, 2017e).

\section{Limited risk of escalation}

The last assumption is that cyber operations present key characteristics that presumably make them highly effective while generating a low risk of escalation, thus particularly suited to use that stays in the gray zone. These are: (1) anonymity and the problems associated with attribution and deniability; and (2) the legal uncertainty surrounding cyber operations, whether for espionage, disruption, or influence (Fitton 2016).

Anonymity being a relatively prevalent feature of cyberspace, the attribution of cyber operations is not only complex and time-consuming at the technical level but also an often delicate, contested, and challenging affair at the political level (Assumpção 2020; Egloff 2019; Rid and Buchanan 2015). Meanwhile, due to the possibility of spoofing and false flag attacks, the chance of perfect technical attribution is low - whether or not this is necessary for political attribution is another debate. This imbalance towards offense is furthermore reinforced by the fact that proponents of cyber operations do not need to achieve perfect unattributable operations; instead, they only need to sow enough confusion and doubt in analysts and policy makers to alter its process (Assumpção 2020). Accordingly, it is unlikely that the resulting verdict of attribution will be so certain (i.e. quality and feasibility) as to justify a traditional military response under the applicable international law regulations (Fitton 2016). This is further reinforced by the fact that cyber operations have - practically and theoretically - a low propensity to lead to deaths, or at least directly attributable death and physical damages (Smeets 2018).

Linked to the issue of attribution, the legality of most cyberattacks and cyberenabled influence operations remains both uncertain and unsettled normatively under international law (Schmitt 2018). This legal gray zone pertaining to cyber operations is thus ripe for exploitation by states and non-state actors who can avoid consensus and formal condemnation (and thus retaliation) for their use of cyber operations. The lack of international norms, however, is a double-edged sword and can also increase the risk of tensions among states, as shown by the spillover to trade war between the United States and China. The lack of consensus 
is rooted in diverging understanding and normative behavior - driven by the respective strategic imperatives of each actor - around various types of cyber operations. For instance, on the one hand, cyber-enabled intelligence conducted for the purpose of gathering and processing information for national security is generally tolerated and expected among states across the whole spectrum between peace and war (Harris 2016; The Economist 2013). On the other hand, economically driven cyberespionage is denounced and deemed by certain states - e.g. the United States - as illegitimate (Harris 2016).

As for cyberespionage, the debates around cyber influence operations can be rooted in differing conceptual approaches and definitions of cyber security. While Western states understand the concept narrowly and close to its technical definition, other states, including China and Russia, understand the concept more broadly. These states include cybersecurity in the concept of information space (Giles and Hagestad 2013). Therefore, Russia and China consider cyber influence operations as tools available to them for international relations, for instance to project power and advance national interests.

\section{Conclusion}

Overall, due to the overarching political fragmentation and intensifying international competition, a number of states, such as Iran, North Korea, the United States, China, or Russia, are increasingly attempting to advance their strategic economic and political interests through other means than war. In an attempt to avoid full-fledged escalations - due, in part, to a logic of cost avoidance as well as the relative imbalance in military power/capabilities - these actors have thus resorted to engaging and competing within the gray zone through the use of tactics of economic or political coercion as well as cyber operations and cyber influence operations. This trend has been particularly reinforced as the various socio-technological transformations of the past years have created plenty of opportunity for exploitation and disruption.

Regarding cyber operations, it is the relative availability and accessibility of cyber weapons and their apparent operational characteristics - flexibility, rapidity, scalability, and limited escalation potential - that help explain why cyber operations have become one of the prevalent instruments of power projection in the gray zone, even when their strategic impact might be elusive. However, despite the widely shared assumption that such operations are a good substitute for conventional military/sabotage operation, their effectiveness and destructiveness should be reconsidered considering the inherent risks, uncertainties, costs, and trade-offs they present.

In practice and according to the analysis of different cases of gray zone conflicts, cyber operations thus seem to be at the same time a novel, efficient, and effective tool for disruption (and to a lesser extent sabotage) while an enhancer and transformer of traditional gray zone activities, such as espionage and influence. Accordingly, it can be reasonably expected that actors operating in the gray zone will continue using, developing, and investing in cyber operations. This is 
particularly true for cyber influence operations, to which cyber operations have proven to be particularly suited in comparison with traditional sabotage.

\section{Notes}

1 There is a whole conceptual debate around the nomenclature pertaining to cyber operations, with numerous scholars differentiating between offensive and defensive cyber operations. In this chapter, it will broadly refer to computer activities by states or statelinked actors that disrupt, deny, degrade, and/or destroy.

2 Gray zone conflicts include variants such as Gray zone tactics/warfare/competition and synonyms such as hybrid/Non-linear/Ambiguous warfare.

3 An American national security concept, it is defined as those actors seeking to change some or all aspects of the existing international environment and world order.

4 Each of these cases have been analyzed in a respective Hotspot Analysis from the ETH Center for Security Studies (CSS). See Hotspot Analysis: Cyber Disruption and Cybercrime: Democratic People's Republic of Korea; Hotspot Analysis: Regional Rivalry between India-Pakistan: Tit-for-tat in Cyberspace; Hotspot Analysis: Use of Cybertools in Regional Tensions in Southeast Asia; Hotspot Analysis: Synthesis 2017: Cyber-Conflicts in Perspective; Hotspot Analysis: Cyber-Conflict between the United States of America and Russia; Hotspot Analysis: Stuxnet; Hotspot Analysis: The Use of Cybertools in an Internationalized Civil War Context: Cyber Activities in the Syrian Conflict; Hotspot Analysis: Cyber and Information Warfare in Elections in Europe; Hotspot Analysis: Strategic Stability between Great Powers: The Sino-American Cyber Agreement; Hotspot Analysis: Cyber and Information Warfare in the Ukrainian Conflict Version 2.

5 Before the adversary has patched his systems.

6 The ties between these individuals and states are, most of the time, blurry and difficult to prove.

\section{References}

All links checked on August 202021.

Al-Rawi, A. K. (2014). Cyber Warriors in the Middle East: The Case of the Syrian Electronic Army. Public Relations Review, 40(3): 420-428. https://doi.org/10.1016/j .pubrev.2014.04.005.

Assumpção, C. (2020, May 6). The Problem of Cyber Attribution between States. E-International Relations. Retrieved from: https:/www.e-ir.info/2020/05/06/the -problem-of-cyber-attribution-between-states/.

Baezner, M. (2018a). Hotspot Analysis: Cyber Disruption and Cybercrime: Democratic People's Republic of Korea. Zurich: Center for Security Studies (CSS). Retrieved from: http://www.css.ethz.ch/content/dam/ethz/special-interest/gess/cis/center-for-securities -studies/pdfs/Cyber-Reports-2018-03.pdf.

Baezner, M. (2018b). Hotspot Analysis: Regional Rivalry between India-Pakistan: Titfor-Tat in Cyberspace. Zurich: Center for Security Studies (CSS). Retrieved from: http://www.css.ethz.ch/content/dam/ethz/special-interest/gess/cis/center-for-securities -studies/pdfs/Cyber-Reports-2018-04.pdf.

Baezner, M. (2018c). Hotspot Analysis: Use of Cybertools in Regional Tensions in Southeast Asia. Zurich: Center for Security Studies (CSS). Retrieved from: https://css .ethz.ch/content/dam/ethz/special-interest/gess/cis/center-for-securities-studies/pdfs/ Cyber-Reports-2018-05.pdf. 
Baezner, M. (2018d). Hotspot Analysis: Synthesis 2017: Cyber-Conflicts in Perspective. Zurich: Center for Security Studies (CSS). Retrieved from: http://www.css.ethz.ch /content/dam/ethz/special-interest/gess/cis/center-for-securities-studies/pdfs/Cyber -Reports-2018-06.pdf.

Baezner, M. and Robin, P. (2017a). Hotspot Analysis: Cyber-Conflict between the United States of America and Russia. Zurich: Center for Security Studies (CSS). Retrieved from: http://www.css.ethz.ch/content/dam/ethz/special-interest/gess/cis/center-for -securities-studies/pdfs/Cyber-Reports-2017-02.pdf.

Baezner, M. and Robin, P. (2017b). Hotspot Analysis: Stuxnet. Zurich: Center for Security Studies (CSS). Retrieved from: http://www.css.ethz.ch/content/dam/ethz/ special-interest/gess/cis/center-for-securities-studies/pdfs/Cyber-Reports-2017-04 .pdf.

Baezner, M. and Robin, P. (2017c). Hotspot Analysis: The Use of Cybertools in an Internationalized Civil War Context: Cyber Activities in the Syrian Conflict. Zurich: Center for Security Studies (CSS). Retrieved from: http://www.css.ethz.ch/content/dam /ethz/special-interest/gess/cis/center-for-securities-studies/pdfs/Cyber-Reports-2017 -05.pdf.

Baezner, M. and Robin, P. (2017d). Hotspot Analysis: Cyber and Information Warfare in Elections in Europe. Zurich: Center for Security Studies (CSS). Retrieved from: https:// css.ethz.ch/content/dam/ethz/special-interest/gess/cis/center-for-securities-studies/pdfs /Cyber-Reports-2017-08.pdf.

Baezner, M. and Robin, P. (2017e). Hotspot Analysis: Strategic Stability between Great Powers: The Sino-American Cyber Agreement. Zurich: Center for Security Studies (CSS). Retrieved from: https://css.ethz.ch/content/dam/ethz/special-interest/gess/cis/ center-for-securities-studies/pdfs/Cyber-Reports-2017-07.pdf.

Baezner, M. and Robin, P. (2018). Hotspot Analysis: Cyber and Information Warfare in the Ukrainian Conflict Version 2. Zurich: Center for Security Studies (CSS). Retrieved from: http:/www.css.ethz.ch/content/dam/ethz/special-interest/gess/cis/center-for-securities -studies/pdfs/20181003_MB_HS_RUS-UKR\%20V2_rev.pdf.

Balduzzi, M., Flores, R., Gu, L. and Maggi, F. (2018). A Deep Dive into Defacement: How Geopolitical Events Trigger Web Attacks [TrendLabs Research Paper]. Trend Micro. Retrieved from: https://documents.trendmicro.com/assets/white_papers/wp-a -deep-dive-into-defacement.pdf.

Barno, D. and Bensahel, N. (2015, May 19). Fighting and Winning in the «Gray Zone». War on the Rocks. Retrieved from: https://warontherocks.com/2015/05/fighting-and -winning-in-the-gray-zone/.

Barrett, P. M. (2019). Disinformation and the 2020 Elections: How the Social Media Industry Should Prepare. Center for Business and Human Rights, New York University STERN. Retrieved from: https://issuu.com/nyusterncenterforbusinessandhumanri/docs /nyu_election_2020_report?fr=sY2QzYzI0MjMwMA.

Boeke, S. and Broeders, D. (2018). The Demilitarisation of Cyber Conflict. Survival, 60(6): 73-90.

Brands, H. (2016, February 5). Paradoxes of the Gray Zone. Foreign Policy Research Institute. Retrieved from: https://www.fpri.org/article/2016/02/paradoxes-gray-zone/.

Buchanan, B. (2020). The Hacker and the State: Cyber Attacks and the New Normal of Geopolitics. Cambridge and London: Harvard University Press.

Cantwell, D. (2017). Hybrid Warfare: Aggression and Coercion in the Gray Zone. Insights, 21(14). Retrieved from: https://www.asil.org/insights/volume/21/issue/14/hybrid -warfare-aggression-and-coercion-gray-zone. 
Carlisle, D. and Izenman, K. (2019). Closing the Crypto Gap Guidance for Countering North Korean Cryptocurrency Activity in Southeast Asia (RUSI Occasional paper). Royal United Services Institute. Retrieved from: https://static.rusi.org/20190412 closing_the_crypto_gap_web.pdf.

Chambers, J. (2016). Countering Gray-Zone Hybrid Threats. Modern War Institute. Retrieved from: https://mwi.usma.edu/wp-content/uploads/2016/10/Countering-Gray -Zone-Hybrid-Threats.pdf.

Cherepanov, A. (2017). TeleBots are back: Supply-chain attacks against Ukraine. Welivesecurity ESET. Retrieved from: https://www.welivesecurity.com/2017/06/30 /telebots-back-supply-chain-attacks-against-ukraine/\#: :text=Conclusions, as $\% 20$ a \%20supply\%2Dchain\%20attack.

Chesney, R., and Citron, D. (2018). Deepfakes: A Looming Crisis for National Security, Democracy and Privacy? Lawfare. Retrieved from: https://www.lawfareblog.com/ deepfakes-looming-crisis-national-security-democracy-and-privacy.

Corn, G. (2018). Cyber National Security: Navigating Gray Zone Challenges In and Through Cyberspace. In: W. S. Williams and M. Ford (eds). Complex Battlespaces: The Law of Armed Conflicts and the Dynamics of Modern Warfare. Oxford: Oxford University Press, pp. 345-428.

Crowdstrike (2016). Use of Fancy Bear Android Malware in Tracking of Ukrainian Field Artillery Units. Retrieved from: https:/www.crowdstrike.com/wp-content/brochures/ FancyBearTracksUkrainianArtillery.pdf.

Dalton, M., Hicks, K. H., Donahoe, M., Sheppard, L., Friend, A. H., Matlaga, M., Federici, J., Conklin, M. and Kiernan, J. (2019). By Other Means-Part 2: Adapting to Compete in the Gray Zone. CSIS. Retrieved from: https://csis-website-prod.s3.amazonaws.com/ s3fs-public/publication/Hicks_GrayZone_II_interior_v8_PAGES.pdf.

Dave, P. and Bing, C. (2019, June 7). Russian Disinformation on YouTube Draws Ads, Lacks Warning Labels: Researchers. Reuters. Retrieved from: https:/www.reuters.com /article/us-alphabet-google-youtube-russia-idUSKCN1T80JP.

Dewar, R. S. (2017). Trend Analysis: Cyberweapons : Capability, Intent and Context in Cyberdefense. Zurich: Center for Security Studies (CSS). Retrieved from: https://css .ethz.ch/content/dam/ethz/special-interest/gess/cis/center-for-securities-studies/pdfs/ Cyber-Reports-2017-06.PDF.

DiResta, R., Schaffer, K., Ruppel, B., Sullivan, D., Matney, R., Fox, R., Albright, J. and Johnson, B. (2018). The Tactics and Tropes of the Internet Research Agency. New Knowledge. Retrieved from: https://disinformationreport.blob.core.windows.net/ disinformation-report/NewKnowledge-Disinformation-Report-Whitepaper.pdf.

Dostri, O. (2020). The Reemergence of Gray-Zone Warfare in Modern Conflicts. Military Review. Retrieved from: https://www.armyupress.army.mil/Journals/Military-Review/ English-Edition-Archives/January-February-2020/Dostri-Gray-Zone/.

Dragos Inc. (2017). Crash Override Analysis of the Threat to Electric Grid Operations. Retrieved from: https://www.dragos.com/wp-content/uploads/CrashOverride-01.pdf.

Echevarria, A. (2016). Operating in the Gray Zone: An Alternative Paradigm for U.S. Military Strategy. Carlisle: Strategic Studies Institute and U.S. Army War College Press.

Egloff, F. J. (2019). Contested Public Attributions of Cyber Incidents and the Role of Academia. Contemporary Security Policy, 41(1): 55-81.

Finkle, J. (2017, April 3). Cyber Security firm: More Evidence North Korea Linked to Bangladesh Heist. Reuters. Retrieved from: https://www.reuters.com/article/us-cyber 
-heist-bangladesh-northkorea/cyber-security-firm-more-evidence-north-korea-linked -to-bangladesh-heist-idUSKBN1752I4.

FireEye Inc. (2019). Double Dragon APT41, a Dual Espionage and Cyber Crime Operation (Special Report). FireEye Inc. Retrieved from: https://content.fireeye.com/apt-41/rpt -apt41/.

Fischerkeller, M. P. and Harknett, R. J. (2017). Deterrence is not a Credible Strategy for Cyberspace. Orbis, 61(3): 381-393.

Fischerkeller, M. P. and Harknett, R. J. (2019, February 19). What Is Agreed Competition in Cyberspace? Lawfare. Retrieved from: https://www.lawfareblog.com/what-agreed -competition-cyberspace.

Fitton, O. (2016). Cyber Operations and Gray Zones: Challenges for NATO. Connections, 15(2): 109-119.

Galperin, E., Marquis-Boire, M. and Scott-Railton, J. (2013). Quantum of Surveillance: Familiar Actors and Possible False Flags in Syrian Malware Campaigns. Electronic Frontier Foundation. Retrieved from: https://www.eff.org/fr/document/quantum -surveillance-familiar-actors-and-possible-false-flags-syrian-malware-campaigns.

Gannon, J. A., Gartzke, E., Lindsay, J. R. and Scharm. P. (2021). The Shadow of Deterrence: Why Capable Actors Engage in Conflict Short of War. Retrieved from: https://peterschram.com/wp-content/uploads/2021/01/gray_zone_web.pdf.

Giles, K. (2016). Handbook of Russian Information Warfare. Rome: NATO Defence College Research Division.

Gomez, M. (2018, November 6). In Cyberwar, There Are Some (Unspoken) Rules. Foreign Policy. Retrieved from: https://foreignpolicy.com/2018/11/06/in-cyberwar -there-are-some-unspoken-rules-international-law-norms-north-korea-russia-iran -stuxnet/.

Grohe, E. (2015). The Cyber Dimensions of the Syrian Civil War: Implications for Future Conflict. Comparative Strategy, 34(2): 133-148. https://doi.org/10.1080/01495933 .2015.1017342.

Guerrero-Saade, J. A. and Moriuchi, P. (2018). North Korea Targeted South Korean Cryptocurrency Users and Exchange in Late 2017 Campaign. Recorded Future. Retrieved from: https:/go.recordedfuture.com/hubfs/reports/cta-2018-0116.pdf.

Harknett, R. J. and Smeets, M. (2020). Cyber Campaigns and Strategic Outcomes. Strategic Studies, 1-34. https://doi.org/10.1080/01402390.2020.1732354.

Harris, E. (2016). Comparing Cyber-Relations: Russia, China, and the U.S. Toronto: Mackenzie Institute. Retrieved from: https://mackenzieinstitute.com/2016/05/ comparing-cyber-relations-russia-china-and-the-u-s/.

Hicks, K. H., Friend, A. H., Federici, J., Shah, H., Donahoe, M., Conklin, M., Akca, A., Matlaga, M. and Sheppard, L. (2019). By Other Means-Part 1: Campaigning in the Gray Zone. CSIS. Retrieved from: https://csis-website-prod.s3.amazonaws.com/s3fs -public/publication/Hicks_GrayZone_interior_v4_FULL_WEB_0.pdf.

Hoffman, F. G. (2007). Conflict in the 21st Century: The Rise of Hybrid Wars. Potomac Institute for Policy Studies Arlington. Retrieved from: https://www.potomacinstitute .org/images/stories/publications/potomac_hybridwar_0108.pdf.

Howard, P. N., Ganesh, B., Liotsiou, D., Kelly, J. and François, C. (2018). The IRA, Social Media and Political Polarization in the United States, 2012-2018 (The Computational Propaganda Project). University of Oxford and Graphika. Retrieved from: https:// comprop.oii.ox.ac.uk/wp-content/uploads/sites/93/2018/12/The-IRA-Social-Media -and-Political-Polarization.pdf. 
Kapusta, P. (2015). The Gray Zone [White Paper]. MacDill Air Force Base: U.S. Special Operations Command.

Kim, S. (2018, February 7). Inside North Korea's Hacker Army. Bloomberg. Retrieved from: https://www.bloomberg.com/news/features/2018-02-07/inside-kim-jong-un-s-hacker -army.

Kozy, A. (2015, June 1). Rhetoric Foreshadows Cyber Activity in the South China Sea. CrowdStrike Blog. Retrieved from: https://www.crowdstrike.com/blog/rhetoric -foreshadows-cyber-activity-in-the-south-china-sea/.

Leed, M. (2015). Square Pegs, Round Holes, and Gray Zone Conflicts: Time to Step Back. Georgetown Journal of International Affairs, 6(2): 133-143.

Mazarr, M. (2015a). Mastering the Gray Zone: Understanding a Changing Era of Conflict. Studies Institute and U.S. Army War College Press.

Mazarr, M. (2015b). Struggle in the Gray Zone and World Order. War on the Rocks. Retrieved from: https://warontherocks.com/2015/12/struggle-in-the-gray-zone-and -world-order/.

Mogato, M. (2017, August 15). Philippines Says China Agrees on no New Expansion in South China Sea. Reuters. Retrieved from: https://www.reuters.com/article/us -southchinasea-philippines-china/philippines-says-china-agrees-on-no-new-expansion -in-south-china-sea-idUSKCN1AV0VJ.

Nakashima, E. and Sonne, P. (2018, June 8). China Hacked a Navy Contractor and Secured a Trove of Highly Sensitive Data on Submarine Warfare. The Washington Post. Retrieved from: https://www.washingtonpost.com/world/national-security/china -hacked-a-navy-contractor-and-secured-a-trove-of-highly-sensitive-data-on-submarine -warfare/2018/06/08/6cc396fa-68e6-11e8-bea7-c8eb28bc52b1_story.html.

Nichols, M. (2019, August 5). North Korea Took \$2 Billion in Cyberattacks to Fund Weapons Program: U.N. Report. Reuters. Retrieved from: https://www.reuters.com/ article/us-northkorea-cyber-un/north-korea-took-2-billion-in-cyberattacks-to-fund -weapons-program-u-n-report-idUSKCN1UV1ZX.

Nocetti, J. (2015). Guerre de l'information: Le web russe dans le conflit en Ukraine. Focus Stratégique, 62: 1-47.

NSFocus Inc. (2016). Distributed Denial-of-Service (DDoS) Attacks: An Economic Perspective. Retrieved from: https://nsfocusglobal.com/company-overview/resources/ ddos-economic-perspective-wp/.

Nye, J. S. (2017). Deterrence and Dissuasion in Cyberspace. International Security, 41(3): 44-71. https://doi.org/10.1162/ISEC_a_00266.

Ornos, E., Remnick, D. and Yaffa, J. (2017, March 6). Trump, Putin, and the New Cold War. The New Yorker. Retrieved from: http://www.newyorker.com/magazine/2017/03 /06/trump-putin-and-the-new-cold-war.

Pettyjohn, S. and Wasser, B. (2019). Competing in the Gray Zone-Russian Tactics and Western Responses. RAND Corporation. Retrieved from: https://www.rand.org/pubs/ research_reports/RR2791.html.

Rid, T. (2013). Cyber War Will not Take Place. Oxford: Oxford University Press.

Rid, T. and B. Buchanan (2015). Attributing Cyber Attacks. Journal of Strategic Studies, 38(12): 4-37.

Rovner, J. (2019, July 16). Cyber War as an Intelligence Contest. War on the Rocks. Retrieved from: https://warontherocks.com/2019/09/cyber-war-as-an-intelligence-contest/.

Sanger, D. (2018). The Perfect Weapon: War, Sabotage, and Fear in the Cyber Age. New York: Crown. 
Scott-Railton, J., Hulcoop, A., Razzak, B. A., Marczak, B., Anstis, S. and Deibert, R. (2020, June 9). Dark Basin: Uncovering a Massive Hack-For-Hire Operation. CitizenLab. Retrieved from: https://citizenlab.ca/2020/06/dark-basin-uncovering-a-massive-hack -for-hire-operation/.

Shanker, T. and Bumiller, E. (2012, October 11). Panetta Warns of Dire Threat of Cyberattack on U.S. The New York Times. Retrieved from: https:/www.nytimes.com /2012/10/12/world/panetta-warns-of-dire-threat-of-cyberattack.html.

Smeets, M. (2018). The Strategic Promise of Offensive Cyber Operations. Strategic Studies Quarterly, 12(3): 90-113.

Solon, O. (2017, May 15). WannaCry Ransomware Has Links to North Korea, Cybersecurity Experts Say. The Guardian. Retrieved from: https://www.theguardian.com/technology /2017/may/15/wannacry-ransomware-north-korea-lazarus-group.

The Economist. (2013, November 2). Rules for spies. The Economist. Retrieved from: https://www.economist.com/leaders/2013/11/02/rules-for-spies.

Timberg, C. and Romm, T. (2019, July 25). It's not Just the Russians Anymore as Iranians and Others Turn Up Disinformation Efforts Ahead of 2020 Vote. The Washington Post. Retrieved from: https:/www.washingtonpost.com/technology/2019/07/25/ its-not-just-russians-anymore-iranians-others-turn-up-disinformation-efforts-ahead -vote/?noredirect.

Valeriano, B., and Jensen, B. (2019). The Myth of the Cyber Offense: The Case for Restraint. Washington: Cato Institute. Retrieved from: https://www.cato.org/policy -analysis/myth-cyber-offense-case-restraint.

Votel, J. L., Cleveland, C. T., Connett, C. T. and Irwin, W. (2016). Unconventional Warfare in the Gray Zone. Joint Force Quarterly, 80(1): 101-109.

Warner, M. (2019). A Matter of Trust: Covert Action Reconsidered. Studies in Intelligence, 63(4): 33-41.

Wirtz, J. J. (2017). Life in the "Gray Zone": Observations for Contemporary Strategists. Defense and Security Analysis, 33(2): 106-114. 